\title{
Edyta Tabaszewska-Zajbert
}

Wroclaw University of Economics and Business e-mail: edyta.tabaszewska-zajbert@ue.wroc.pl

ORCID: 0000-0001-6636-1528

\author{
Agnieszka Sokołowska-Durkalec \\ Wroclaw University of Economics and Business \\ e-mail: agnieszka.sokołowska-durkalec@ue.wroc.pl \\ ORCID: 0000-0002-0708-9162
}

\section{TOWARDS A TURQUOISE ORGANIZATION - \\ PERSONAL CHANGE OF EMPLOYEES AND ITS SOCIO-CULTURAL BARRIERS}

W KIERUNKU TURKUSOWEJ ORGANIZACJI ZMIANA OSOBISTA PRACOWNIKÓW

\section{JEJ BARIERY SPOLECZNO-KULTUROWE}

DOI: $10.15611 / \mathrm{pn} .2019 .9 .17$

JEL Classification: M10, M12, M14

\begin{abstract}
Summary: A turquoise organization is one of the new organization models, created in the course of research by the Belgian business practitioner F. Laloux. The basic assumptions for the functioning of this organization, otherwise known as a teal organization, are a sense of mission, wholeness of humanity and self-management. The aim of the study is to indicate the personal development of employees as the main condition for transformation into a turquoise organization. In addition, the basic social and cultural barriers of the expected personal change were pointed out, with particular emphasis on Polish conditions. The basic barriers include, first of all, a low level of social trust together with unacceptable openness in expressing emotions, a faulty educational system, and barriers related to organizational culture. The study was based on literature studies and the presentation of the results of selected foreign empirical studies.
\end{abstract}

Keywords: turquoise organization, teal organization, personal change, personal development, socio-cultural barriers.

Streszczenie: Turkusowa organizacja jest jednym z nowych modeli organizacji, wyodrębnionym w toku badań przez belgijskiego praktyka biznesu F. Laloux. Podstawowe założenia funkcjonowania tego typu organizacji to poczucie misji, pełnia człowieczeństwa oraz samozarządzanie. Na twardym, wymagającym rynku takie założenia dotyczące prowadzenia biznesu mogą się wydawać utopijne, dla wielu osób nawet niezrozumiałe, a jednak w praktyce są przykłady funkcjonowania przedsiębiorstw według tego modelu, odnoszących 
sukcesy finansowe. Celem opracowania jest wskazanie na rozwój osobisty pracowników jako główny warunek transformacji w organizację turkusową. Ponadto wskazano na podstawowe bariery społeczno-kulturowe oczekiwanej zmiany personalnej, ze szczególnym uwzględnieniem polskich uwarunkowań. Do podstawowych barier zaliczono przede wszystkim niski poziom zaufania społecznego wraz z nieakceptowalną otwartością w wyrażaniu emocji, wadliwy system edukacyjny oraz bariery związane z kulturą organizacyjną. Opracowanie powstało na podstawie studiów literaturowych oraz prezentacji wyników wybranych obcych badań empirycznych.

Słowa kluczowe: organizacja turkusowa, żywa organizacja, zmiana osobista, rozwój osobisty, bariery społeczno-kulturowe.

\section{Introduction}

One of the latest frames of a flexible organization model is the turquoise organization (TO) model proposed by F. Laloux, in which three pillars of integrated principles are most important: self-management, evolutionary goal (sense of mission) and wholeness. Their implementation is manifested in the form of many daily practices and shows the image of the organization's maturity. A turquoise organization is a new, coherent organizational model that corresponds to a new stage in the development of human awareness, a new paradigm of teamwork and a new way of managing the organization [Laloux 2016].

Its creation requires the reorientation of the existing principles of the organization and requires employees to be highly aware of themselves as individuals and their own role in the organization, which allows them to move from external to internal assessments of decisions. Thanks to this, it becomes possible to reverse the order in force in existing organizational models. Success or wealth are no longer needed for a good life for everyone, for an employee of an organization. Ensuring a good life becomes the most important thing, and only its effect can be recognition, success, wealth and love [Pluta 2017, p. 307]. A self-aware employee is a person sure of his/ her own value, talents and at the same time looking for a job that will ensure his/her self-fulfillment and broadly understood life success - turquoise organizations can be such places.

With the emergence of the concept of turquoise organizations, based on the high awareness of all employees, there are doubts whether the functioning of enterprises according to this model is really possible. F. Laloux shows specific organizations in his book Reinventing Organizations [Laloux 2016], there are also publications presenting further examples, also in Poland, but they are still relatively few. ${ }^{1}$ So what can contribute to transforming an organization into a teal model, and what stands in the way? In the authors' opinion, both opportunities and barriers to functioning should be seen primarily in the social and cultural sphere.

${ }^{1}$ For example: Brewa s.c. (Kalisz), Marco Sp. z o.o. (Gliwice), Kamsoft Podlasie Sp. z o.o. (Warsaw and Zambrów), Mentax S.A. (Koszalin) [Blikle 2000, pp. 79-85; Blikle 2019; Skrzypek 2017, p. 9]. 
Therefore the purpose of this study is to indicate the personal development of employees, leading to a profound change in personnel, as the main condition for transformation into a turquoise organization. In addition, the basic socio-cultural barriers of this change were pointed out, which included primarily a low level of social trust together with unacceptable openness in expressing emotions, a faulty educational system, and barriers related to organizational culture. ${ }^{2}$ This was done on the basis of literature studies and the presentation of the results of selected foreign empirical studies. ${ }^{3}$

The authors understand a personal change here as an internal change regarding beliefs, habits, motivations and emotions felt, leading to a new role. In this case, the role of an independent and creative person, consciously involved in his/her life, also in the professional area - as an employee of a turquoise organization.

\section{Turquoise organization - basic assumptions}

A turquoise organization is a concept introduced in 2015 by F. Laloux - a Belgian business practitioner. Another term that captures their essence is teal organizations. F. Laloux explains that as human consciousness evolves, this also evolves our mode of organization. Looking at the history of mankind, he identifies different levels of organizations, calling them in order of colours: red, amber, orange and green, and identifies the emergence of these turquoise (teal) organizations.

All organizations in our society do not move from one level to the next until a new level of consciousness appears. Some organizations are still red, reflecting a despotic mode of management of organizations (for example the mafia or clans), others are amber, governed by strict rules and processes (churches or government agencies), others are orange, organized around the notion of meritocracy and accountability (multi-national enterprises today), and others are green, reflecting the notion of stakeholder management and others (their centre is a strong, motivating organizational culture), a limited but growing number of them have become teal organizations, a mode of organization corresponding to a new level of consciousness [Querenet 2018, p. 27].

The transformation of organizational structures rests, among others, on the fact that they become more flexible, characterized by the occurrence of nested teams with a high degree of autonomy in terms of defining tasks by employees and individual contracting networks [Laloux 2016, p. 376]. Another element of the organization that requires change is the organizational culture, which should be independent and contextual along with the desire to be a living organism with its own life force shaped

2 The indicated barriers are only an assumption that requires verification in the next stage of the research process, including empirical research.

${ }^{3}$ A review of the literature showed a significant theoretical and empirical gap in the issues discussed in the study. The result of the query of the most important databases of scientific publications is 14 publications containing the term turquoise organizations in the title, and 8 -teal organizations. 
by the organization's purpose and not by the personal assumptions, norms and aspirations of the founders and leaders [Laloux 2016, pp. 278, 280].

A turquoise organization is based on three main pillars, called breakthroughs [Kurki, Wilenius 2016, p. 4; Laloux 2016, pp. 276-278]:

- Self-management - TO discovered the key to effective operation, even on a large scale, using a system based on relationships between employees, without the need for a hierarchy ${ }^{4}$ or consensus model. Antonyms are expressing this evolution of such an approach: partnership instead of hierarchy, trust instead of control, cooperation instead of competition. This model of organizing, based on self-organized teams, creates order without hierarchies. In practice, self-management means that the teams doing the actual work have autonomy in deciding how they actually go about their work;

- Evolutionary purpose - TO has a sense of mission, determines its own course of action, in an open discussion with employees. Based on their own choices, employees spontaneously undertake various tasks and assign roles adapted to individual capabilities and skills. Instead of trying to control the future, they listen to what is happening and co-decide on the strategic direction of the organization. In traditional organizations the role of the leadership is to create a strategy and see to its implementation plan. The self-organizing model forgoes strategy for an intent about where the organization wants to go. The leader's task is to sense this natural tendency and support it. Elements corresponding to this breakthrough are: coherence between the goals of the organization and the goals of employees, future planning and profit;

- Wholeness - TO has developed a consistent set of practices that even encourage its members to return to internal fullness and bring to work everything they are. The dominant features here are: a focus on authenticity, which allows employees to regain the internal whole; creating a safe and open work environment that allows reflection, creativity, development and building healthy relationships with people and the surrounding world; as well as moving away from promoting a narrow professional identity. Authenticity in terms of not needing to differentiate between "home" and "work" identity is central in the ethos of self-managed organizations. This feature provides for an intensified feedback and evaluation system of the organization, as "stupid questions", failures, and calls for assistance are not only tolerated, but used as a way for collective learning to occur. Wholeness thus refers to aiming for creating a sense of safeness within the organization.

However, there are opinions that the description offered by F. Laloux [2016] could be considered as "an old product in new attractive packaging". According to

${ }^{4}$ As Hopej-Tomaszycka and Hopej emphasize, the lack of hierarchical structures is only arbitrary, pointing to the main idea. The authors point to the organizational solutions adopted in turquoise organizations, having the features of a hierarchy, although based on partner relationships or consisting in helping those members of the organization who need it [Hopej-Tomaszycka, Hopej 2018, p. 222]. 
J. Rosiński, Gareth Morgan's theory, Images of Organization, from 1980, described similar phenomena: prison, political system, machine, culture, organism, and brain. Some key words of Laloux's theory were also described in the second half of the 20th century, for example self-management is described in detail in Ken Blanchard's paradigm: Situational Leadership [Rosiński 2018, p. 244].

A.J. Blikle points out that turquoise organizations practice what has been known for years in the form of various types of management techniques, for example management techniques through exceptions or by delegating of rights, the use of which was to give space to managers in focusing on development issues in a given area of the company's activity, teamwork or propagating the expected organizational culture [Blikle 2017, p. 63].

The strength of turquoise organizations lies in the practical application of the principles promoted by the classical school of humanization. Based on the analysis of modern trends in management, including the emergence of new organizational models, i.e. turquoise, agile or holocratic, one can state the renaissance of these assumptions. The basic principles of the turquoise organization model are consistent with what was developed almost a hundred years ago, to this day still known as the Hawthorne Effect, the pyramid of Maslow's needs, or McGregor's Theory X and Y. It was confirmed then that employees treated as a partner, trusted and receiving freedom in the selection of people for the team, as well as in the implementation of the entrusted task, work with greater commitment, are able to make a greater effort, enter into closer relationships and thus achieve higher results [Sokołowska-Durkalec, Tabaszewska-Zajbert 2017, p. 31]. The needs of development and self-fulfillment, as well as taking responsibility for entrusted tasks and commitment to professional life are natural features of a human being, provided that the right conditions are provided to the employee. Turquoise organizations are skilled in stimulating these traits, thereby fostering full humanity.

It should also be noted that many of the solutions adopted in turquoise organizations can be found in popular management concepts. Among those popular one can mention total quality management, knowledge management and human resources management; also organizational models such as learning or intelligent organizations are based on the trust, commitment and creativity of employees. It seems, however, that the turquoise organization model goes further, beyond the organizational framework and management instruments used, and supporting the broadly understood personal development of employees.

It is worth emphasizing that the change of organization towards a lively, non-hierarchical one, results not only from the internal need for transformation caused by the desire to gain a business advantage. Enterprises will be forced to make such a change, primarily due to the increasing complexity of the environment. In such cases, it is no longer possible to manage organizations based on control and hierarchical decision-making structures that cause difficulties in the flow of non-codified knowledge resources, as well as the filtering and modification of relevant 
information, resulting in a decrease in its value. The transition to self-management and the expansion of the number of units responsible for a joint decision approach eliminates the need for codification and filtering information, which in turn leads to a more complete picture of the complex situation [Kurki, Wilenius 2016, p. 5].

The specific features of the TO model apply to all areas of the organization's operation: from strategic assumptions enshrined in the actual mission and organizational structure based on autonomous teams, through applied management instruments (concepts, methods, techniques), supporting the development of individuals, groups and the entire organization, up to an organizational culture based on such values as trust, responsibility and cooperation.

\section{Personal change as a condition of transformation into TO}

In order for the organization to transform into a turquoise process, many elements need to be changed - from the organizational structure, management tools, to an organizational culture conditioning the success of the whole process. Change requires above all commitment and internal awareness transformation from top management. They should be the first to give up the need to control employees for the sake of trust and freedom of decision-making, including them in the management process and noticing personality unrelated strictly to their role in the organization. The managers of the company, acting as a certain model, have a decisive influence on the accepted attitudes, behaviour and shaping of beliefs that create the organizational culture.

Laloux emphasizes that the transformation of an organization into a model of turquoise management is not easy, mainly due to its psychological aspects. Particularly in relation to management, there may be a lot of resistance due to the loss of existing hierarchical power. Management often fiercely opposes change, and its opposition is the strongest barrier in the transition period [Laloux 2016, p. 322].

This is due to the fact that (as demonstrated by the organizational game theory), a key advantage of taking a managerial position is a sense of power, resulting from even greater access to information. A turquoise organization is moving away from a power-based hierarchy, and the flow of information is multi-channel. What current managers have to face is, above all, their own beliefs about employees. In practice, the approach characteristic of X McGregor's theory is still lingering, according to which employees are lazy, irresponsible and in order to put effort into doing work, they must be constantly monitored, which results not only in management levels, but also the organizational units responsible for control. Management therefore creates organizational structures in response to a lack of confidence in employees, and its formalization is associated with a low-responsibility assumption. Therefore, in order for the organization to transform into a turquoise one, it is necessary to change the worldwide view of the management. It seems obvious that this is a long-term process, requiring, above all, a personality change of individuals. The creator of the model of a teal organization claims that part of the management team will not be able to make 
such a change and, consequently, will leave the organization [Laloux 2016, p. 322]. In turn, A. Blikle points out that moving away from the hierarchical management structure does not imply the need to get rid of these people, which would result in the loss of valuable resources of knowledge, skills and experience, but the need to free them from the obligations related to the current organization of work [Blikle 2017, p. 63].

Being a leader in a turquoise organization is not about setting goals, motivating subordinates to achieve them or participating, but about giving freedom in making decisions and carrying out tasks. In practice, the leader should adopt the attitude of a coach, asking questions, attentive to employees' potential, but without giving specific guidelines and solutions. As a consequence, there should be a partnership relationship between employees, not a paternalistic relationship [Jack 2018, pp. 196-200].

The authors also see the opportunity for the necessary internal transformation of the management in the use of coaching, which on the one hand helps to discover their own potential and adapt to new roles in a turquoise organization, but also allows employees to support their talents and commitment to the organization. ${ }^{5}$ It is not an easy and quick process, but it is necessary for TO's values and assumptions to have a real chance of occurrence and dissemination. Managers who actually consider their employees trustworthy, hardworking, responsible and creative, do not need to exercise power, shape control apparatus and arouse anxiety about a job, position, status, support, etc. ${ }^{6}$

Mutual trust reduces the risk and uncertainty of making business decisions in a complex environment. Trust is understood here as the expectation that everyone does their job reliably, regardless of the control exercised over it. It is worth emphasizing that research on trust in organizations has confirmed its important role in effective communication, as well as in organizational cooperation and innovation, which are important dimensions in self-managing organizations [Ellonen, Blomqvist, Puumalainen 2008, pp. 160-181; Mayer, Davis, Schoorman 1995, pp. 709-734].

Only a change in the management approach will allow for the creation of selfmanagement teams, which are the basis of turquoise organizations. Members of such teams take responsibility for jointly obtained work results, monitor them, actively collecting data on them, and make necessary changes in their work in response to the needs identified. The duties and rights of self-management teams may include: division of labour, resource allocation, budget expenditure, working methods and their development, performance assessment as well as recruitment and development of new employees. Thus, decisions that traditionally belonged to the management team are handed over to the members of the teams [Bondarouk et al. 2018, p. 8].

For employees who are trusted to actually be able to actively participate in shaping a teal organization, they must undergo a similar personal transformation as

${ }^{5}$ It should be emphasized that the role of a leader or a coach is not reserved solely for management, just as operational functions are not only performed by employees. In a turquoise organization, rigid rules do not apply, and every employee can develop in every aspect, area or role.

${ }^{6}$ More on this topic: [Tabaszewska-Zajbert, Sokołowska-Durkalec 2018, pp. 617-629]. 
existing managers. They should also get support in identifying and developing their own potential, in the form of training, coaching and tools necessary for independent management. All team members should be trained in problem solving, cooperation techniques and communication skills [Bondarouk 2018, p. 20].

The goal is not only the effectiveness of teams in the organizational aspect, but above all to increase employees' awareness of their own values, priorities and strengths, leading to taking responsibility not only for work, but for a successful life, giving a sense of accomplishment in various areas. This leads to the establishment of the third foundation of a turquoise organization - being full of humanity. As a consequence, the company will acquire a competent employee who is passionate and committed. Drucker clearly emphasizes that one of the most important challenges of a 21 st century organization is to help employees recognize their talents and use them for the benefit of the employee and the organization [Drucker 2000, see: Wellin 2010, p. 25].

Querenet emphasizes that the transformation into a turquoise organization depends on the personal development of employees, with particular significance of the personnel transformation of the current management staff. The author recommends looking at the practices applied from the point of view of the three main pillars of a teal organization and questioning them. Propagating change does not yet mean a real transformation. The author notes that it is helpful to apply a change management approach that prefers open communication, rolling planning instead of long-term planning, and building a team of people coordinating the transformation process to make changes. He also recommends attending coaching sessions to achieve real personal development [Querenet 2018, pp. 27-30].

\section{Basic socio-cultural barriers}

Considering the purpose of this study, one should ask the question whether such deep internal transformation of employed persons is possible. Many social and cultural factors can stand in the way.

In turquoise organizations, mutual trust is the basic value. The survey on the levels of trust in Poland, conducted by CBOS since 2002, invariably indicates that Poles show distrust towards their own society. In 2018, only slightly more than a fifth of respondents $(22 \%)$ assume that most people can be trusted, and more than three-quarters $(76 \%)$ adhere to the principle of maintaining extreme caution and suspicion in relations with others. Not much has changed in this respect in recent years. The belief that it is better not to trust others in principle is now shared as much as it was two, four or six years ago, although less frequently than in the period 2002-2006, when Poles professed this principle even more widely. Over the past sixteen years only the years between 2008 and 2010 stand out, when, as it turned out only for a short time, they became a little more open and trusting towards others [CBOS 2018]. 
According to the authors, the education system currently functioning in Poland is another barrier in adopting the teal organization model. Employees of a turquoise organization should know what they can do well, what are their resources and priorities, what they want to achieve and to what extent they want to develop. Unfortunately, the knowledge of one's own strengths and values, as well as the ability to communicate assertively are the competences of few employees. These competences should already be gained at the stage of early education, and not of adults enter into professional life (although of course this is possible).

It seems that most Polish schools do not respond to the needs of the future labour market, including the model specific to turquoise organizations. Individualism, creativity, self-awareness or expressing one's views are not supported. Instead, obedience and matching to a certain pattern are preferred. Building awareness of one's strengths and developing skills to deal with emotions are virtually nonexistent, and training to acquire social competences are marginal. As a consequence, young people, functioning in a system based on comparing results, are rather equipped with a lack of self-confidence and low self-esteem. Such baggage is not conducive to the later adoption of the qualities of a turquoise organization's employee.

The authors' fear the negative impact of the education system on the development of individuals, fortunately this is not confirmed by the results of empirical research conducted among final year students of MA studies at the University of Economics in Wroclaw in the field of Management. The subject of the study were the preferred values and patterns of functioning at the target workplace. ${ }^{7}$ The group of representatives of the $Z$ generation (born in the period 1995-2010) is characterized by flexibility in the way it operates and functions. They are motivated by development and learning that gives them a sense of self-fulfillment and fulfillment. The activities focus on effects. At work, they prefer collaboration, knowledge sharing and participation. They take responsibility for their contribution to the implementation of tasks, expect open communication, access to information and stability of employment [Grzesik, Kwiecińska 2018, p. 530]. However, one may have doubts as to the representativeness of the results obtained, due to the selection of respondents familiar with the subject of the latest trends in management.

All these features are conducive to effective employment in a teal organization. Therefore it may turn out that organizations will have to adapt to the values of the young generation, for example by adopting a turquoise model. The issue of organizational culture remains, depending largely on the attitude of the management and the dominant age group in the employment structure. If there are barriers to

7 In order to obtain answers to the questions posed, quantitative research using the CAWI method was conducted. The MindSonar psychometric test with Cronbach's alpha coefficient ranging from 0.7 to 0.85 was used. MindSonar is a functional psychological system that explores how people think in specific situations (contexts) and how they have internal motivations, values and beliefs. 85 students took part in the study [Grzesik, Kwiecińska 2018, p. 523]. 
accessing information, reluctance to share knowledge and low creativity in response to rigid patterns of behavior, then the potential of young people may not be fully exploited.

Another barrier is the issue of openness in expressing emotions. Both the awareness of emotions and the ability to communicate and deal with them are not common among Polish society. Emotional education is lacking, and talking about one's own feelings in the workplace is not socially acceptable for the most part. At the same time, these competences are preferred in turquoise organizations, whose main foundation is full humanity, and therefore also the emotional sphere. A. Blikle also recognizes that the inability to talk about emotions is one of the main barriers to changing the organizational culture to suit the discussed model of organization. The fear of revealing such emotions as fear of change or fear of revealing problems effectively block openness to remove their sources and search for new solutions [Blikle 2015, pp. 142-143].

Synthesizing, for organizations to be able to successfully adopt the turquoise model, it is necessary to eliminate socio-cultural barriers, making changes at many different levels from national and social to group and individual.

\section{Conclusions}

Turquoise organizations are attracting more and more interest from both researchers and management practitioners, while the practical application can be discussed in the case of a marginal number of organizations. The main barriers to adopting this model can be social and cultural factors, perceived at various levels: from individual, through group, cultural, to aspects related to values, methods of communication or obligations at the level of national culture, also taking into account religious beliefs. They have a significant impact on psychological barriers. From the individual's point of view, it is important to reformulate beliefs about oneself, other people and the world, deeply rooted in the subconscious.

Einstein said that problems cannot be solved from the same level of consciousness that caused them [Skrzypek 2017, p. 3]. Therefore it becomes necessary to overcome thought and emotional patterns, and this requires courage and time. The basic recommendation for management practitioners is reflection on actual and declared key values and the mission of the organization, as well as building emotional openness between employees.

There is no doubt that issues related to the adaptation of turquoise organization's characteristics require empirical research. This is a complex, multi-faceted topic in both management sciences and psychology. It seems interesting to look for answers to questions about the type and strength of existing barriers, instruments that can be used in an enterprise to facilitate employees' internal transformation, or conditions for effective transformation. Another interesting issue is the recognition of the relationship between the specific features of the operation of turquoise organizations and related models, such as agile or holocratic organizations. 


\section{Bibliography}

Blikle A.J., 2017, Doktryna jakości. Rzecz o turkusowej samoorganizacji, Helion, Gliwice.

Blikle A.J., www.moznainaczej.com.pl (10.09.2019).

Bondarouk T. et al., 2018, Organisational Roadmap Towards Teal Organisations, Emerald Publishing.

CBOS, 2018, O nieufności i zaufaniu, Komunikat z Badań, nr 35.

Drucker P., 2000, Managing knowledge means managing oneself, Leader to Leader, no. 16.

Ellonen R., Blomqvist K., Puumalainen K., 2008, The role of trust in organisational innovativeness, European Journal of Innovation Management, vol. 11, Iss. 2.

Grzesik K., Kwiecińska M., 2018, Systemy wartości i modele mentalne pokolenia Z preferowane w miejscu pracy, [in:] Stroińska E., Geraga M. (eds.), Wyzwania w zarzadzaniu zasobami ludzkimi we wspótczesnych organizacjach. Od teorii do praktyki, Przedsiębiorczość i Zarządzanie, tom XIX, zeszyt 8, część I, Wydawnictwo SAN, Łódź-Warszawa.

Hopej-Tomaszycka M., Hopej M., 2018, Struktury organizacyjne turkusowych organizacji, Zeszyty Naukowe Politechniki Śląskiej, Seria: Organizacja i Zarządzanie nr 130, Wydawnictwo Politechniki Śląskiej w Gliwicach.

Jack R., 2018, Building Teal Organizations with Servant Leadership?, [in:] Dierendonck D.V., Patterson K. (eds.), Practicing Servant Leadership: Developments in Implementation, Springer International Publishing AG.

Kurki S., Wilenius M., 2016, Trust makes this organisation unique. Looking at the future of work through two human-centric organisations, European Journal of Futures Research, December.

Laloux F., 2016, Pracować inaczej, Studio Emka, Warszawa.

Mayer R.C., Davis J.H., Schoorman D.F., 1995, An integrative model of organizational trust, Academy of Management Review, vol. 20, no. 3.

Pluta A., 2017, Kanon wartości pracowników i wartości organizacji jako podstawa do wdrożenia koncepcji Organizacji Turkusu, Marketing i Rynek, nr 4.

Querenet B., 2018, Reinventing organizations: insights into the journey!, Workforce Solutions Review, July-September.

Rosiński J., 2018, Creating an Evolutionary Teal Organization on a Step-by-step Basis. A Case Study, [in:] Klimas P., Lipińska A. (eds.), Emerging Challenges in Modern Management, Entrepreneurship and Management, volume XIX, iss. 6.

Sokołowska-Durkalec A., Tabaszewska-Zajbert E., 2017, Perspektywy rozwoju koncepcji społecznej odpowiedzialności przedsiębiorstwa, Management Forum, vol. 5, no. 4.

Skrzypek A., 2017, Organizacja turkusowa - szansa na nowa jakość zarzqdzania czy utopia?, Problemy Jakości, nr 12.

Tabaszewska-Zajbert E., Sokołowska-Durkalec A., 2018, Coaching jako narzędzie wsparcia turkusowego modelu organizacji, [in:] Stroińska E., Geraga M. (eds.), Wyzwania w zarzqdzaniu zasobami ludzkimi we współczesnych organizacjach. Od teorii do praktyki, Przedsiębiorczość i Zarządzanie, tom XIX, zeszyt 8, część I, Wydawnictwo SAN, Łódź-Warszawa.

Wellin M., 2010, Zarzadzanie kontraktem psychologicznym. Zaangażowanie pracowników w zwiększenie wydajności firmy, Wolters Kluwer, Warszawa. 